\title{
THE "DOUBLE EMERGENCY” AND THE SECURITIZATION OF THE HUMANITARIAN APPROACH IN THE ITALIAN RECEPTION SYSTEM WITHIN THE PANDEMIC CRISIS
}

\author{
Giuliana SANÒ', Omid FIROUZI TABAR"
}

COBISS 1.01

\begin{abstract}
The "Double Emergency" and the Securitization of the Humanitarian Approach in the Italian Reception System within the Pandemic Crisis

The Coronavirus outbreak has revealed the critical situation that can emerge when isolation and quarantine measures are applied to migrants living in reception and detention centers and overcrowded contexts. The paper focuses on events that affected two Extraordinary Reception Centres (CASs) and a Hotspot, located in Northern and Southern Italy. Although the humanitarian paradigm still represents the most functional form of government, this historical moment's particularity led the authors to reflect on the continuity and change it brings. They hypothesize that the health crisis has downsized the action of care within humanitarian spaces favoring the strengthening of traditional securitarian solutions.

KEYWORDS: Coronavirus, reception system, migrants, Italy
\end{abstract}

\section{IZVLEČEK}

»Dvojno izredno stanje» in sekuritizacija humanitarnega pristopa k italijanskemu sistemu sprejemanja med pandemijo

Izbruh koronavirusa je razkril kritičen položaj, do katerega lahko privedejo izolacijski in karantenski ukrepi, uporabljeni na migrantih, ki živijo v prenatrpanih sprejemnih centrih in centrih za pridržanje. Članek obravnava dogajanje v dveh izrednih sprejemnih centrih (CASs) in v tako imenovanem hotspotu, ki se nahajajo na severu oziroma jugu Italije. Čeprav je humanitarna paradigma še vedno najbolj funkcionalna oblika upravljanja, je posebnost tega zgodovinskega trenutka avtorja spodbudila k razmisleku o kontinuiteti in spremembah, ki jih prinaša. Po njunem mnenju je zdravstvena kriza prispevala $\mathrm{h}$ krčenju oskrbe $v$ humanitarnih okoljih na račun krepitve tradicionalnih sekuritarnih rešitev.

KLJUČNE BESEDE: koronavirus, sistem sprejemanja, migranti, Italija

Post-doc fellow, University of Messina, Via Lanterna 45, 98164 Messina, Italy; gsano@unime.it, https://orcid.org/0000-0002-8971-1540.

\| Phd in sociology of cultural phenomena and normative processes, Via Premuda 18, 35138 Padua, Italy; tabaromid@yahoo.it, https://orcid.org/0000-0001-7015-0416. 


\title{
INTRODUCTION ${ }^{1}$
}

\begin{abstract}
"This virus does not have any borders and treats all equally; while you stay at home, we have to stay in the camp where there is no guarantee of health safety."

(Amiri, a 16-year-old from Afghanistan living in Ritsona camp) ${ }^{2}$
\end{abstract}

With these words, an Afghan teenager living in the refugee camp of Ritsona, Greece, illustrates with extreme clarity and simplicity the main similarities and differences activated by the SARS-CoV-2 epidemic. If, on the one hand, the virus shows that it does not have borders and does not treat its hosts clinically based on social differences, on the other hand, the measures adopted to prevent and control the contagion do not materialize in the same way for everyone, thus disproving the belief that we can talk about a presumed democratic nature of this virus (Tazzioli 2020; Sani 2020).

A good example is given by those asylum seekers who, in the long and sometimes exhausting wait for the end of the asylum application process, find themselves living in large tents or overcrowded encampments lacking the most basic social and health guarantees or, again, in the widespread network of isolated apartments peripheral to urban contexts (Altin, Sanò 2017).

A year after its beginning, we have seen how the pandemic produces effects and has different impacts on society, inscribing itself along those lines of class, color, and gender that characterize contemporary capitalism. It has placed at the center of attention, in their mutual interaction and juxtaposition, issues such as domestic violence against women; the unprecedented vulnerability of the poorest, most precarious, and economically marginal social groups; the condition of radical social abandonment of migrants and a parallel exacerbation of racism, especially institutional racism.

The Italian reception system, as pointed out by several parties (Guadagno 2020; Camilli 2020; Giammarinaro, Palumbo 2020), is a sector where the impact of the health crisis has manifested itself in particularly problematic terms:

Evidence shows that this vulnerable population has a low risk of transmitting communicable diseases to host populations in general. However, refugees and migrants are potentially at increased risk of contracting diseases, including COVID-19, because they typically live in overcrowded conditions without access to basic sanitation. The ability to access health-care services in humanitarian settings is usually compromised and exacerbated by shortages of medicines and lack of health-care facilities. Conditions in refugee camps are concerning [...] These camps usually provide inadequate

1 The Introduction and Conclusion were written by both authors, Omid Firouzi Tabar wrote the section on Treviso and Giuliana Sanò wrote the section on Messina.

2 https://www.businessinsider.com/residents-of-refugee-camp-greece-all-tested-covid-192020-4?IR=T. 
and overcrowded living arrangements that present a severe health risk to inhabitants and host populations. (Kluge et al. 2020: 1238)

A document by the European Centre for Disease Prevention and Control (ECDC) ${ }^{3}$ shows how even some important government agencies have highlighted the critical situations that emerge by applying isolation and quarantine measures to migrants living in reception and detention centers, in overcrowded contexts, marked by forced cohabitation.

In this regard, researchers have identified a relationship between these and the increase in stigma toward the migrant population. The latter can therefore lead to a rise in problems related to mental health, sexual and gender violence, and also to the concealment of health conditions and diseases. ${ }^{4}$

We refer, in particular, to the formation of a common way of thinking that, in this phase of the health crisis, fuels mistrust toward migrants and attributes to them ever new responsibilities such as the spread of the virus and the increase in infections (Mukumbang et al. 2020; Tallarek et al. 2020; Pitzalis 2020; Spada 2020, Tiwari 2020), leveraging an ideological armamentarium and racist and inferiorizing narratives.

In addition to the classic representations and stereotypes used to portray migrants as "dangerous," "criminals," and "terrorists" - and to the more recent ones that see them playing, instead, the role of "cheaters" and "perfect victims" who must earn the "gift" of reception - today there is the risk of making room for the image of the migrant as "plague victim" and "pest," a threat to public health.

This paper focuses on events that, between the summer and autumn of 2020, affected an Extraordinary Reception Centre (Centri di Accoglienza Straordinaria - CAS) located in Northern Italy (Treviso) and two facilities (Hotspot and CAS) in Southern Italy (Messina). ${ }^{5}$ Although the geographical contexts examined are different, they present some common features that can indicate some general trends. The two cities observed - Treviso and Messina - share the presence of numerous and varied facilities for the reception of people who apply for international protection and refugees, reflecting the image of a fragmented and uneven supply chain characterized by extraordinary interventions and an emergency organizational dynamic. The multilevel

3 Guidance on infection prevention and control of COVID-19 in migrant and refugee reception and detention centres, 2020: 5.

4 These same terms have been used (Cordova, forthcoming, Lo Cascio, locco 2020; D'Ignoti 2020, Kluge et al. 2020) to describe the anomalies that during the first phase of confinement have affected migrant workers in the agricultural sector living in ghettos or informal encampments. Specifically, we refer to the impossibility for these people to comply with the preventive measures adopted by the government (constantly washing their hands, wearing a mask, respecting physical distance) due to the material conditions that exist in these spaces, which are almost always devoid of running water, minimum habitability requirements, and are also overcrowded.

5 The Italian reception model is characterized by a multi-level system: identification centers (Hotspots), first reception centers (Cpsa, Cpa, Cara, Cas, Hub), second reception centers (Sai and other local projects) and repatriation centers (Cpr). 
nature of the types of reception and the extreme marginality of public and ordinary solutions have progressively imposed a highly discretionary referral of the beneficiaries, greatly eroding the sphere of their rights. The 2018 "Salvini Decree" intensified these processes while placing them in a tendency of continuity with the past (Firouzi Tabar 2020), with significant social consequences on the lives of migrants.

This law has further produced social effects of inferiorization and racialization by placing itself in a framework of structural orientations activated mainly to achieve forms of subaltern or differential inclusion (Ambrosini et al. 1995; De Genova 2002; Mezzadra 2013, Fabini 2017, Sbraccia 2020). In these forms, "humanitarian" control (Malkki 1996; Agier 2005; Fassin 2012, 2019) often alternates and intertwines with attitudes aimed at exclusion, implemented by return policies and through a considerable use of restrictive and punitive devices of the police, criminal, and prison type.

We intend to inscribe our reflection within an analytical field that contrasts the solidity of paradigms with the fluidity of the movements, contractions, and shifts that can occur in such contexts of power.

Although the humanitarian paradigm, punctually analyzed and described over the years by the authors mentioned above, continues to represent a form of government extremely functional to the production of "docile bodies," the historical moment's particularity, characterized as an emergency within the emergency, leads us to reason on the transformations and forms of continuity and change that result. We hypothesize, therefore, that the health crisis has downsized the action of care within humanitarian spaces (Cutitta 2021), favoring, on the contrary, the strengthening of 1) more traditional security solutions, 2) the dynamics of exclusion from the plan of socio-economic supports (bonuses, subsidies, benefits, and refreshments), and 3) the processes of hyper-stigmatization and criminalization of migrants. ${ }^{6}$

Starting from the case studies that we are about to describe, we will try to observe how, in a setting that represents a sort of double emergency for reception, the practices and procedures of "care," "cure," and "control" (Agier 2005: 50) were intertwined and alternated in the context of the pandemic, and to verify whether there was a definite shift toward the dimension of control. At the same time, we will see how the people living in the centers responded to this shift and to the transformations imposed by the health emergency.

$6 \quad$ By leveraging the feeling of fear of contagion and the promotion of a media and political communication that attributes to the entry and stay of migrants in the territory a heavy responsibility in the spread of the virus (Devakumar et al. 2020), the health emergency has actually legitimized the introduction of new processes of discrimination and stigmatization. We can consider, for example, the choice of using quarantine ships to prevent the docking of migrants. 


\section{TREVISO: A RECEPTION THAT KILLS ${ }^{7}$}

A considerable presence of large structures (regional hubs) and a laughable use of ordinary tools (former SPRAR ${ }^{8}$ ), below the national average, in favor of an overwhelming predominance of extraordinary and emergency solutions, make Veneto a unique case in the national context.

Entirely consistent with the picture of extreme fragmentation described above, the Veneto system looks like a network of small and large CASs, primarily located in the countryside and therefore far from urban contexts or on the outskirts of cities and, at least until 2018, with the image of three large, first-reception camps (Prandina, Cona, Bagnoli) in each of which, for several years, between 600 and 1300 migrants have found "hospitality."

Thus, overcrowding, peripheralization, social-spatial isolation, and, the usual consequence of emergency dynamics, an extreme discretion of the managing bodies in the organization of support and services, characterize the Veneto model overall.

In this territory, as found by some empirical investigations (Pasian, Toffanin 2018; Firouzi Tabar 2019), asylum seekers have been frequently confronted with systematic violations of primary rights such as social and health rights, segregation and compression of individual freedom spaces, and infantilizing processes and paternal treatments of their choices and behaviors, in constant activation of typical humanitarian tools and more traditional repressive and criminalizing actions.

It is within this structural framework that, over the years, the plan of counter-moves and resistance of those who have found themselves in the reception facilities has taken shape, and it is from this scenario that we can try to read the implications of the pandemic and its management.

As the operator of a cooperative in Padua interviewed in April 2020 (therefore in the heart of the first lockdown) reminds us, two key issues immediately emerged, one linked to involuntary cohabitation in the spaces and the other to the absence of strategies, protocols, and intervention plans aimed at preventing and containing contagions:

7 The considerations presented in this study are part of a broader research on the organization of the reception of asylum seekers in Veneto. For this contribution, in-depth interviews were conducted with some managers and operators of medium-sized facilities during the months of April and May 2020, at the dawn of the pandemic crisis. Limitations due to the ongoing "lockdown" at that time made it necessary to proceed through the telematic platform "Zoom". The study of the events surrounding the former Serena Barracks has been supported by several informal conversations, by phone and in person, with some activists who have long been engaged in support of the applicants of the camp, by a documentary analysis sitographic and addressed to the local media, and by a long meeting with one of the four applicants arrested as a result of the protests that will be described below.

8 SPRAR stands for System of Protection for Asylum Seekers. Between 2018 and 2020, the name was changed to SIPROIMI - Protection System for Holders of International Protection and for Unaccompanied Foreign Minors. This acronym has now been replaced by SAI, which stands for Reception and Integration System 
Almost nowhere have they adopted standard procedures and this is a problem because we go to work disoriented and do not know how to deal with emergencies and risk situations. The main criticality is the fact that we have in the apartments people who are already living a forceful coexistence with people who they have not chosen, the quarantine exacerbates this situation. From a sanitary point of view, it is still impossible to isolate a person in case of a positive swab. Only a few facilities that have empty apartments can do it.

The coordinator of another cooperative, interviewed during the same period, points out how the pandemic and lockdown have produced tensions regarding isolating in the facilities and the consequent forced cohabitation:

The most critical thing is the impossibility of isolation, there are no single rooms, which in possible COVID cases creates conflicts and suspicions that exacerbate the environment. The discomfort is high because no one has chosen to live with those they live with and these cohabitations are sometimes long and conflicting. Some people can't stand this forced togetherness all day and disobey the rules and hang around. This psychological aspect is very important. If tapping into their resilience and relying at times only on that which was already a problem to keep in balance before, now becomes even more of an issue.

In the summer of 2020, the country was preparing to cancel all restrictions, which later led to new Christmas lockdowns. Concurrently, in Treviso, the accumulated contradictions after many months blew up the precarious balance within one of the largest CASs in Veneto located in the former Serena Barracks, managed by the cooperative Nova Facility SRL. In a few years, the cooperative has completely changed the scope of intervention, becoming - not without criticism - one of the protagonists of the reception in Veneto and increasingly at the national level. ${ }^{9}$

On June 11, 2020, the tensions and the heightened discomfort already present in the camp, which on that date hosted 300 people, exasperated by the management of the pandemic crisis, exploded into anger among the beneficiaries and a harsh and dramatic process of criminalization for some of them.

Following the report of an operator testing positive for COVID, the Prefecture and the ULSS decided to close the camp that day and isolate it by blocking its access,

9 Initially active in the field of energy and construction, Nova Facility SRL has been dealing with reception since 2015 and its declared revenues jumped from 719 thousand euros in 2014 to over 6 and a half million in 2019. Today it also manages the largest CAS in the Veneto region in Oderzo, the former Mattei barracks in Bologna used as a regional HUB, and the Hotspot in Lampedusa. In addition to the many complaints and protests expressed by the beneficiaries against the type of management of the camp, on August 9, 2020, the Prosecutor of Treviso Michele Dalla Costa opened an "information file" that prompted the judges to collect information on the presence of any negligence in the measures to prevent the sudden spread of contagion in the structure. 
which triggered two days of widespread and intense protests. After having spent the first lockdown imprisoned for months inside a camp that appeared as a "natural" hotbed toward which the authorities had never activated any health security protocol, the prospect of a new quarantine produced in the migrants both the fear of losing hard-earned jobs outside the camp and the - well-founded - fear of exposure to the uncontrollable contagion. This fear was especially because, since the first outbreak and the management of the first health screening, no particular organizational strategies had been activated to manage contagion risk.

On July 30, 2020, 137 people tested positive, and in less than ten days, the number rose to 257 .

New protests followed the decision to quarantine the facility once again. Through the field testimonies of some activists who have long supported the applicants and of a local journalist, ${ }^{10}$ who collected the direct voice of the migrants from the camp, we know that the common spaces such as kitchens, canteens, and showers were still used after the emergence of the first positive case by people who were negative, positive, and waiting for a swab, that the beds had not been moved further apart following the many swabs carried out, and that, in general, internal protocols had not been activated to differentiate the daily treatment of the applicants in light of the test results.

The protests, therefore, seem to take shape mainly in reaction to the health trap materialized in the light of the serious lack of protocols and standards of management of the crisis in progress, as well as to follow previous actions of resistance that had long marked the scenario of what is still one of the largest CASs in the Veneto region."

During the summer of 2020, the media presented the ongoing protests and the response to them very harshly, even more so than it had portrayed similar protests, or even more intense and radical ones, which had taken place over the years. On August 19, 2020, four applicants were arrested and imprisoned in Treviso, accused of devastation and looting and kidnapping for the June protests.

To reinforce this repressive orientation, after two months, by order of the Department of Penitentiary Administration (DAP), they were moved to four different prisons and placed in a state of "special surveillance" (Article 14-bis of the Penitentiary Code). This harsh measure provides for the isolation of particularly dangerous

10 Local journalist Alice Carlon and local solidarity organizations such as Association Caminantes, social center (an Italian squat) "Django" and trade union ADL Cobas.

11 During a protest organized inside the camp in March 2017, a letter was sent to the director of the camp containing an articulate set of claims that give us a good idea of the structural problems that have long marked this structure. Among other things, the letter reported the constant overcrowding, the degradation and dilapidation of housing compared to prison cells, and several violations of social and health rights. The letter was published in its entirety on the Melting Pot website: https://www.meltingpot.org/Treviso-ex-Caserma-Serena-I-richiedenti-asilo-in-protesta.html\#.YA7tehbSJPY. 
subjects. They were labeled dangerous ${ }^{12}$ for having criticized the failed management of contagions in the former Barracks. It is not difficult to see the punitive intent of this set of criminal and prison measures with which we proceed to criminalize a collective action of claiming rights. A punitive reaction to behaviors dictated in many cases by fear - as reported several times by Abdou, the first of the four to be released from prison, during a long and intense conversation - the fear of losing his job, the fear of becoming infected, the fear provoked by the police who had surrounded the reception center for hours.

On November 7, 2020, one of the four young people affected by this measure, 23-year-old Chaka Ouattaro from Mali, could not stand the violent backlash and decided to take his own life using parts of his clothing as a noose. This is the epilogue of a story of institutional violence and mismanagement of a service such as reception. Still, it is also the story of the government's repressive and securitizing twist of migration in times of COVID-19, a securitarian and criminalizing orientation punctually accompanied by the public media narration that hastened to name the four boys as "violent," "troublemakers," and "criminals."

\section{FROM BARBED WIRE TO SANITARY CONFINEMENT: THE CASE OF MESSINA AND THE ESCAPE OF MIGRANTS FROM IDENTIFICATION AND RECEPTION FACILITIES ${ }^{13}$}

The case related to the structuring of the reception system in the city of Messina is interesting because it allows us to materially describe the extent to which the health emergency has constituted a coefficient of continuity and change in the lives of people living in the reception system. In particular, we will examine the lines of continuity and the transformations that have affected an Extraordinary Reception Centre (CAS) and a Hotspot there.

The reception center has been active in the city since 2014 and is intended for the reception of asylum seekers. The Hotspot, on the other hand, was opened in 2017 and responds to the need, dictated by the 2015 European Agenda, to identify people who have just arrived on the territory and to differentiate them according to

12 The details regarding the criminal framework in which the four applicants were placed, the process of imprisonment, and the decision to apply the measures of special surveillance have been analyzed in a contribution to be published in Antigone's report (Firouzi Tabar, Maculan 2020). This contribution highlighted, for example, the crucial limitation that these migrants encounter in taking advantage of the alternative measures to prison, as they have enormous problems in indicating a suitable domicile for the application of these measures.

13 With regard to the case study conducted in Messina, we must note that the data and material reported in the text were collected by Giuliana Sanò in the period between March and August 2020. The impossibility of carrying out ethnographic research with traditional field instruments due to the pandemic meant that the research focused mainly on the news spread by social media and the main media and information channels. This analysis was complemented by telephone interviews with reception workers and migrants present in the area. 
their country of origin, following the legislation that defines those who come from countries considered "safe" as ineligible for the procedure for requesting protection.

However, the main difference between the two centers is that while the reception center is an open place, the Hotspot is a closed place. People cannot leave the latter until the identification and status differentiation procedures are completed.

The two facilities are located in large, abandoned barracks in the middle of a working-class neighborhood with a long history of housing and social-economic problems. ${ }^{14}$ The media attention surrounding this area of the city began immediately after the opening of the Hotspot, following a protest that the inhabitants of the neighborhood had improvised to prevent the transfer to the facility of a group of people who had just arrived at the port of Messina.

Before that day, the coexistence between the CAS and the working-class neighborhood had not caused much concern. What prompted the neighborhood inhabitants to change their attitude? According to the media, it was the escape of some people that worried the local population. Taking advantage of the proximity of the containers to people's homes, dozens of people confined to the Hotspot had climbed onto the roofs of the houses in the days before the protest in an attempt to escape. If - from a media point of view - it was necessary to focus on the fear of the inhabitants, frightened by the possibility that those escapes on the roofs could one day turn into episodes of theft, what escaped the attention of the local media were the real reasons for those escapes and how the Hotspot's detention nature determined them. ${ }^{15}$

While the presence of migrants in the neighborhood had not previously caused fear among the locals, it goes without saying that the perception of insecurity which had grown little by little among the inhabitants - was due, first of all, to the structural conditions of the center, surrounded by high walls and barbed wire, and, above all, to the feeling of fear that those two objects generally project toward the outside world. In other words, it was not the fact that the migrants were free to move around the neighborhood that determined the feeling of fear among the locals, but rather the fact that they were locked up in a detention center and made escape attempts to free themselves. What we can derive from this circumstance is, therefore, the value of the material conditions of a place - in this case, surrounded by fences and barbed wire - in activating a perception of general insecurity. Indeed, the need to lock these people up in a detention center went hand in hand with the belief that, ultimately, they were "criminals."

This reasoning on the projection of the feeling of fear, determined by the physical and material characteristics of a structure, is linked to what we have already tried to clarify at the beginning of this contribution, regarding the role played by

14 For an in-depth study of the dynamics of interaction between the Hotspot and the inhabitants of the working-class neighbourhood, see the work of Sanò (2018).

15 https://messina.gazzettadelsud.it/foto/archivio/2017/10/19/migranti-alla-gasparro-protesta-dei-residenti-b41bcece-9eea-40e4-ae3a-a0f549f45d0e/. 
the confinement measures - barriers and fences - in the stigmatization processes directed at the migrant population locked up in the reception centers during the health emergency.

What happened at the beginning of the pandemic in the two facilities may better clarify the meaning of this statement since the feeling of fear provoked by the health crisis eventually led to the agitation of the entire local population and the temporary closure of the two facilities. ${ }^{16}$

During the first months of the outbreak, the local political debate focused on the same reasons that had prompted the media to consider the locals' concerns in 2017. Once again, the population's fears were aroused by the escapes enacted by people locked up in reception centers. However, if in the first circumstance, in 2017, the escapes were mainly attributable to the Hotspot migrants' attempt to evade the logic of the European Asylum Agenda, in this case, the escapes also involved migrants housed in the reception center. With the outbreak of the epidemic and the need to implement reliable and safe confinement measures, the managers of the two facilities changed the destination of the two centers, swapping the location of the "guests." As the Hotspot structure offered more possibilities of escape, during the summer of 2020, all persons awaiting identification were transferred to the extraordinary reception center, which was considered safer thanks to a surveillance system with barriers and turnstiles. The managers thus transformed the function of the extraordinary reception center to respond to the need for confinement and control to contain the virus so that, against the regulations, this space became a fullyfledged closed center. ${ }^{17}$ However, the lack of differentiated spaces to divide those who had just arrived from those who had already completed the quarantine period led to the beginning of sporadic escapes from the center. In the absence of this differentiation, all the people present in the reception center were indiscriminately denied not only the right to leave the structure but, above all, the right to safeguard their own safety and health security.

This case, in particular, helps us to prove our initial hypothesis, in which we argued that, with the onset of the pandemic event, the humanitarian regime drastically reduced the actions of care toward the people in the reception system, favoring the use of strategies aimed exclusively at the control and limitation of personal freedom. Convinced that it was no longer a safe place, many people in the center responded by fleeing and abandoning it.

However, whereas in 2017, the escapes from the Hotspot had merely attracted the attention of the media and residents, who were frightened by the detention nature of the center from which the "migrants/criminals" were escaping, in the case

16 This article in // Giornale reports the news of the escapes from the Hotspot and the tough stance taken by the mayor: https://www.ilgiornale.it/news/cronache/de-luca-chiude-lhotspot-messina-e-abusivo-ministero-ha-5-1877946.html.

17 This article refers to the dismantling of the Hotspot and the transfer of people to the CAS. https://normanno.com/cronaca/nuova-fuga-da-bisconte-de-luca-basta-migranti-a-messina/. 
of 2020, the escapes took on the contours of a problem related to public order and health security, which were put at risk by the new representation of the "migrants/ plague spreaders."

Having become a public order problem, the escapes that occurred during the sanitary confinement were used by the local authority as a pretext to act on issues from which it had hitherto been excluded since the location and operation of prefectural reception facilities is a matter beyond the competence of the municipal administration. In this context, what happened in the weeks following the escapes from the reception center seems paradoxical. While, on the one hand, the Italian Ministry of the Interior declared illegitimate the order issued by the president of the Region of Sicily, according to which every reception center in Sicily would have to be closed to limit the possibility of arrivals and, therefore, of contagion; on the other hand, the local prefecture allowed the mayor, in his capacity as the person primarily responsible for the health and safety of the city, to decide to empty and temporarily close the two reception centers. In short, the health emergency legitimized a series of anomalies, both at the organizational and decision-making level, which, as in the case just reported, had extremely adverse effects and repercussions on the general conditions of the material existence of the people in the reception centers.

\section{CONCLUSION}

In this contribution, we have tried to read the consequences that the COVID-19 pandemic has generated in the lives of migrants living in the reception system, presenting the two case studies within a general plan of reconfiguration of migration governance devices.

In doing so, we examined the connection between the current health emergency and the structurally emergent nature of migration policies. We have also seen how, in the context of that sort of hybridization between care and control (Fassin 2012; Agier 2005) that characterizes the humanitarian paradigm, some reception management practices, fueled by a reinforced feeling of fear of the foreigner, in many cases socially constructed as an "infector," have been animated by security and repressive measures toward the migrant population living in facilities, especially in large ones.

In particular, the critical reflection on the measures of confinement and quarantine adopted within first reception centers allowed us to establish lines of continuity and to trace the directions taken by the changes introduced by the health emergency. From this point of view, the case studies reported in the text confirm, on the one hand, the presence of continuity in the processes of marginalization, invisibilization, and inferiorization of the subjects living in reception facilities. On the other hand, they document the dramatic change that has taken place within these places with the onset of the pandemic. In this scenario, the epidemic took the conditions of existence of migrants in reception to extremes, legitimizing the limitation of personal freedoms to 
the extreme, the use of violence, and indiscriminate forms of control and repression. Although this legitimacy is based on the humanitarian regime's emergency nature, which foresees the constant oscillation between the dimension of care and that of control, the tendency to privilege the plan of control over that of care has taken on a certain relevance in our eyes. The abandonment of any program of care and support and the criminal/prison response of the institutions to the claims of the applicants in Treviso and the transformation of the reception center in Messina into an actual detention cage give, in our opinion, some alarming signs in this direction.

Since this shift took place in the context of a health crisis, in which public health protection should be the only priority, it becomes more necessary than ever to document what happened in the reception centers during these months. To show how migrants are not only excluded from social-health care and support but also how they end up embodying the image of constant danger in all circumstances. The escapes from the reception center in Messina and the protests in the CAS in Treviso confirm that, even when faced with harsher living conditions, the subjects do not give up on reactions and counter-conducts. By opposing the processes of inferiorization and de-subjectification, they constantly give rise to tactics of resistance, sometimes through individual choices, strategies, and behavior, sometimes through collective claims that have been repeatedly reported in many contexts (Agier 2005; Campesi 2014; Manocchi 2014; Fontanari 2017; De Genova, Garelli \& Tazzioli 2018, Firouzi Tabar 2019).

If it is true that within the emergency regime - and more than ever now in a context of global health crisis - the lives of applicants are exposed to discrimination and dynamics of social segregation and institutional violence and if, as Katerina Rozakou reminds us: "hospitality, seen in the form of a gift, includes the stranger in the social world of the host, though it is a temporary and conditional inclusion in which the host holds the monopoly of agency" (2012: 565), it seems to us that the reactions of subjects to this framework of governance, whether individual or collective, need to be framed in a way that goes beyond the rigid and distorting categories of "nonpersons" and "bare life" (Robins 2009). 


\section{REFERENCES}

Agier, Michel (2005). Ordine e disordini dell'umanitario: Dalla vittima al soggetto politico. Rifugiati 5, 49-65.

Altin, Roberta, Sanò, Giuliana (2017). Richiedenti asilo e sapere antropologico: Una introduzione. Antropologia Pubblica 3/1, 7-34.

Ambrosini, Maurizio, Lodigiani, Rosangela, Zandrini, Sara (1995). L'integrazione subalterna: Peruviani, eritrei e filippini nel mercato del lavoro italiano. Quaderni ISMU 3, 2-33.

Camilli, Eleonora (2020). COVID-19. Prassi improvvisate e difformi: Ecco cosa è successo nei centri d'accoglienza. Redattore Sociale, https://www.redattoresociale. it/article/notiziario/covid19_prassi_fai_da_te_improvvisate_e_difformi_ecco_ cosa_e_successo_nei_centri_d_accoglienza (1 Jul. 2020).

Campesi, Giuseppe (2014). Confinati sulla soglia: Etnografia dei centri per richiedenti asilo in Puglia. Passaggi di frontiera: Osservatorio sulla detenzione amministrativa degli immigrati e l'accoglienza dei richiedenti asilo in Puglia (ed. Luigi Pannarale). Pisa: Quaderni dell'altro diritto, Pacini Editore (in the press), 37-71.

Cutitta, Paolo (2021). Tra spazio umanitario e spazio esternalizzato, Lavoro Culturale, https://www.lavoroculturale.org/tra-spazio-umanitario-e-spazio-esternalizzato/paolo-cuttitta/2021/ (17 Feb. 2021).

D'Ignoti, Stefania (2020). How Coronavirus Hits Migrants and Asylum Seekers in Italy, TheNew Humanitarian, https://www.thenewhumanitarian.org/news/2020/03/16/ italy-coronavirus-migrants-asylum-seekers (16 Mar. 2020).

De Genova, Nicola (2002). Migrant "Illegality" and Deportability in Everyday Life. Annual Review of Anthropology 31, 419-447.

De Genova, Nicola, Garelli, Glenda, Tazzioli, Martina (2018). Autonomy of Asylum? The Autonomy of Migration Undoing the Refugees Crisis Script. The South Atlantic Quarterly 117/2, 239-265.

Fabini, Giulia (2017). Managing Illegality at the Internal Border: Governing through "Differential Inclusion" in Italy. European Journal of Criminology 14/1, 46-62.

Fassin, Didier (2012). Humanitarian Reason: A Moral History of the Present. Los Angeles: University of California Press.

Fassin, Didier (2019). Le vite ineguali: Quanto vale un essere umano. Milan: Feltrinelli. Firouzi Tabar, Omid (2019). L'accoglienza dei richiedenti asilo tra segregazione e resistenze: Un'etnografia a Padova e Provincia. Lungo i confini dell'accoglienza: Migranti e territori tra resistenze e dispositive di controllo (eds. Giulia Fabini, Omid Firouzi Tabar, Francesca Vianell). Rome: Manifestolibri, 175-212.

Firouzi Tabar, Omid (2020). Le pareti permeabili dell'accoglienza e la "continuità" dei Decreti Salvini. Studi Emigrazione LVII/220, 528-546.

Firouzi Tabar, Omid, Maculan, Alessandro (2021). XVII Rapporto di Antigone sulle condizioni della detenzione. 
Fontanari, Elena (2017). It's my Life. The Temporalities of Refugees and Asylumseekers within the European Border Regime. Etnografia e Ricerca Qualitativa 3/2020. Bologna: II Mulino, 25-54.

Giammarinaro, Maria Grazia, Palumbo, Letizia (2020). COVID-19 and Inequalities: Protecting the Human Rights of Migrants in a time of Pandemic (Migration Policy Practice).

Guadagno, Lorenzo (2020). Migrants and the COVID-19 Pandemic: An Initial Analysis, IOM 60, 1-25.

Iocco, Giulio, Lo Cascio, Martina (2020). II virus dello sfruttamento, Jacobin Italia 7/2020, 99-101.

Kluge, Hans Henri P. et al. (2020). Refugee and Migrant Health in the COVID-19 Response. The Lancet, 31 Mar. 2020, https://doi.org/10.1016/S0140-6736(20)30791-1.

Malkki, Liisa H. (1996). Speechless Emissaries: Refugees, Humanitarianism, and Dehistoricization. Cultural Anthropology 11/3, 377-404.

Manocchi, Michele (2014). Richiedenti asilo e rifugiati: Processi di etichettamento e pratiche di resistenza. Rassegna italiana di sociologia 2. Bologna: II Mulino, 385-410.

Mezzadra, Sandro, Neilson, Brett (2013). Border as Method, or, the Multiplication of Labour. Durham: Duke University Press.

Mukumbang, Ferdinand C. et al. (2020). Unspoken Inequality: How COVID-19 has Exacerbated Existing Vulnerabilities of Asylum-seekers, Refugees, and Undocumented Migrants in South Africa. International Journal for Equity in Health 19/141, 2-7.

Pasian, Pamela, Toffanin, Angela Maria (2018). Richiedenti Asilo e Rifugiate nello SPRAR: Contraddizioni nel Sistema d'Accoglienza. Mondi Migranti 1, 127-145.

Pitzalis, Silvia (2018). La costruzione dell'emergenza: Aiuto, assistenza e controllo tra disastri e migrazioni forzate in Italia. Argomenti: Rivista di Economia, Cultura e Ricerca Sociale 10, 103-132.

Pitzalis, Silvia (2020). Il continuum dell'emergenza. Criticità strutturali e mutamenti nel sistema di accoglienza prima e durante la pandemia da COVID-19. Illuminazioni 53, luglio-settembre, 56-85.

Robinson, Steven (2009). Humanitarian Aid Beyond "Bare Survivor": Social Movement Responses to Xenophobic Violence in South Africa. American Ethnologist 36/4, 637-650.

Rozakou, Katerina (2012). The Biopolitics of Hospitality in Greece: Humanitarianism and the Management of Refugees. American Ethnologist 39/3, 562-577.

Sanò, Giuliana (2018). Spazio prodotto e Spazio produttore: La relazione tra il sistema di accoglienza e due territori a Messina. Sociologia urbana e rurale 117 (ed. Maurizio Bergamaschi, Valeria Piro). Milan: Franco Angeli, 59-76.

Sanò, Giuliana (2020). Fare etnografia al tempo del COVID-19: Continuità e fratture alla luce delle misure adottate per far fronte all'emergenza sanitaria. Illuminazioni 53, luglio-settembre, 3-26. 
Sbraccia, Alvise (2020). Pericolosi e funzionali, gli stranieri nel pensiero socio-criminologico. I migranti sui sentieri del diritto: Profili socio-criminologici, giuslavoristici, penali e processualpenalistici (eds. Francesca Curi, Federico Martelloni, Alvise Sbraccia, Elena Valentini). Torino: Giapichelli Editore, 3-8.

Spada, Stefania (2020). Tra cecità corticale e vecchi vizi: Riflessioni sui processi di esternalizzazione e distanziamento. Illuminazioni 53, luglio-settembre, 32-55.

Tallarek, Marie et al. (2020). Towards Inclusionary and Diversity-sensitive Public Health: The Consequences of Exclusionary Othering in Public Health Using the Example of COVID-19 Management in German Reception Centres and Asylum Camps. BMJ Global Health 5, 1-7.

Tazzioli, Martina (2020). Covid's Borders: Peer-to-Peer Surveillance and "Common Good," Political Economy Research Centre, https://web.archive.org/ web/20200414041810/https://www.perc.org.uk/project_posts/covids-borderspeer-to-peer-surveillance-and-common-good/ (23 Jun. 2021).

Tiwari, Badri Narayan (2020). The Body in Surveillance: What to do with the Migrants in the Corona Lockdown. Borders of an Epidemic. COVID-19 and Migrant Workers (ed. R. Samaddar). Kolkata: Calcutta Research Group, 42-47. 


\section{POVZETEK}

\section{»DVOJNO IZREDNO STANJE« IN SEKURITIZACIJA HUMANITARNEGA PRISTOPA K ITALIJANSKEMU SISTEMU SPREJEMANJA MED PANDEMIJO Giuliana SANÒ, Omid FIROUZI TABAR}

Leto dni po izbruhu se posledice in vplivi pandemije v družbi kažejo na različne načine. Izbruh koronavirusa je v ospredje postavil družinsko nasilje nad ženskami, izjemno ranljivost najrevnejših, najslabotnejših in ekonomsko marginaliziranih družbenih skupin, radikalno družbeno zapuščenost migrantov in hkratni rasizem. Na kritični položaj migrantov, ki zaradi izolacije in karantene prisilno sobivajo v prenatrpanih sprejemnih centrih in centrih za pridržanje, so opozorile številne nevladne organizacije.

Članek se osredotoča na dogodke, ki so med poletjem in jesenjo 2020 zaznamovali dva Izredna sprejemna centra (CASs) in t. i. hotspot v severni oziroma južni Italiji. Čeprav humanitarna paradigma kot oblika vladanja izjemno dobro funkcionira v proizvodnji "pokornih teles«, je posebnost tega zgodovinskega trenutka, ki ga označuje izredno stanje znotraj izrednega stanja, oba avtorja napeljala k refleksiji o transformacijah, kontinuiteti ter spremembah, ki jih prinaša. Po njuni hipotezi je zdravstvena kriza skrčila obseg oskrbe na humanitarnih območjih (Cutitta 2021) in v nasprotju z obdobjem pred krizo (1.) okrepila bolj tradicionalne sekuritarne rešitve, hkrati pa (2.) okrepila dinamiko izključevanja iz načrtovanja socioekonomske podpore; prav tako so se (3.) okrepili tudi procesi hiperstigmatizacije in kriminalizacije migrantov. Na dveh območjih zbrani etnografski podatki so pokazali na prepletanje in spreminjanje praks in postopkov »pomoči«, »oskrbe« in »nadzora« med pandemijo, hkrati pa so omogočili preverjanje, ali je prišlo do povečanja nadzora. Kritična refleksija zapiranja in karantenskih ukrepov, uveljavljenih v prvih sprejemnih centrih, je avtorjema omogočila ugotavljati kontinuitete in slediti spremembam, ki so jih povzročile izredne zdravstvene razmere.

Študije posameznih primerov po eni strani potrjujejo kontinuiteto procesov marginalizacije, to je, osebe, ki živijo v sprejemnih centrih, narediti neopazne, po drugi strani pa dokumentirajo dramatične spremembe. Opustitev oskrbnih in podpornih ukrepov ter kaznovanje oziroma zapiranje migrantov v Trevisu kot odziv na njihove prošnje ter preobrazba sprejemnega centra v Messini v dejansko kletko, so alarmantni signali. Poleg raziskovanja procesov preoblikovanja upravljanja migracij in represivnih ukrepov, uperjenih proti migrantom v obeh sprejemnih centrih, sta študiji primerov avtorjema omogočili, da sta dokumentirala odziv ljudi v centrih na vse večji nadzor in spremembe. Pobegi iz sprejemnega centra v Messini in protesti v Trevisu dokazujejo, da se njihovi stanovalci kljub zaostrenim življenjskim razmeram ne odrekajo uporu. 